\title{
The Role of Audit Regulation on The Relationship between Audit Quality, Corporate Governance and Firm Value
}

\author{
$1^{\text {st }}$ Bambang Prayogo $1,2^{\text {nd }}$ Meco Sitardja ${ }^{2}$ \\ \{bprayogo60@yahoo.com ${ }^{1}$, msitardja@gmail.com ${ }^{2}$ \} \\ Trisakti University, Indonesia ${ }^{1}$, Agung Podomoro University, Indonesia ${ }^{2}$
}

\begin{abstract}
This study examined the role of audit regulation on the effect of corporate governance and audit quality on firm value with earning management as intervening. This study examined using structural equation modeling method with the approach of partial least squares (SEM-PLS). The research sample is purposive with a total of 79 manufacture companies listed on the Indonesia Stock Exchange in period 2008-2015 with 480 observation years. The results showed audit regulation influence positively on audit quality. Independent commissioner and audit quality influence positively on firm value, while audit committee and firm value shows no significant. Independent commissioner and audit quality influence negatively on earnings management, while audit committee and firm value shows no significant. Earnings management influences negatively on firm value. The changes of audit quality is significantly effect on earnings management mitigation in companies so firm value that represented on stock price can be analyzed more carefully in long term period view.
\end{abstract}

Keywords: Corporate Governance, Audit Quality, Audit Regulation, Earnings Management, Firm Value.

\section{Introduction}

The essence of the establishment of a company is to improve the welfare of its owners or shareholders, or to maximize shareholder wealth through increasing the value of the company becomes an important goal (Brigham and Houston, 2001). This is confirmed by Siallagan and Machfoedz (2006) which states that the main goal of the company is to maximize the value of the company. The value of a company is the present value of the company's profits in the present and the future (Baye and Prince, 2014). This is what makes the value of the company as very important in investment transactions (Moeljadi and Supriyati, 2014). The better the value of the company, the greater the level of investment in the company.

Changes in company value are not only perceived from the company's financial statements. This is because companies have high social values such as economic, social and environmental. However, financial statements are information for investors in making decisions to make investments (Moeljadi and Supriyati, 2014). According to Sudiyatno, Puspitasari and Kartika (2012), an accounting statement that provides various measurements of financial ratios on company performance can be used as a barometer of the company's success which is used as a benchmark for investors to invest. This is because 
financial ratio analysis can be used to predict financial difficulties, operational results, current and future financial conditions where this can be a guide for investors to see the company's past and future performance (Moeljadi and Supriyati, 2014). According to Bapepam Regulation No. Kep-51 / PM / 1996 as of January 17, 1996, companies going public are required to include relevant financial ratios in order to predict company value. The increase in company value can be achieved if the company is able to operate by achieving targeted profits. This profit enables companies to pay dividends to shareholders, increase company growth and maintain the company's survival. This is in line with the research of Siallagan and Machfoedz (2006) which states that the lower the quality of earnings creates bad decision-making for investors and creditors so that the market performance of a company also decreases as reflected in its stock price (Fama, 1978).

Problems will occur when the relevance of earnings as a measure of the company's financial performance is faced with earnings management practices by managers. Gunny (2009) classifies earnings management in three categories, namely fraudulent accounting, accrual management, and real earnings management. Fraudulent accounting includes the selection of accounting that violates generally accepted accounting principles. Accrual earnings management includes accounting choices that are allowed in generally accepted accounting principles that try to mask or obscure the actual performance of the company (Dechow and Skinner, 2000).

Thus an important effort to be able to be done to overcome earnings management is to limit management's authority in calculating the profits of a company and the limitation of management authority mentioned can be done with preventive actions and corrective actions. There are two preventive measures that can be taken to limit earnings management activities which are internal factors of the company, namely corporate governance, while corrective actions which are external factors of the company are high audit quality of audits conducted by the Public Accountant Office or Public Accountant for the report corporate finance.

Research Gap is not yet optimal in the implementation of Audit Quality and Corporate Governance. This is due to the occurrence of additional KAP / AP sanctions for each audit regulation. In addition, there have been financial cases of public companies in Indonesia until 2015. Finally, the occurrence of errors in the audit process at the Big-4 KAP during the 20122017 period. So the novelty of this research is on how the relationship between the implementation of audit regulation and audit quality. This relationship will certainly influence the contribution of audit quality and governance to earnings management and corporate value. In other words, the novelty proposed is in terms of the contribution of audit quality and governance to earnings management and the value of the company will be different if it takes into account the existence of a range of audit regulations and audit quality.

The present study investigate the role of audit regulation on the relationship between audit quality, corporate governance and firm value. The objective of the study are as follow:

1. To determine the influences of audit regulation on audit quality.

2. To determine the influences of commissioner board on firm value.

3. To determine the influences of audit committee on firm value.

4. To determine the influences of audit quality on firm value.

5. To determine the influences of commissioner board on earnings management.

6. To determine the influences of audit committee on earnings management.

7. To determine the influences of audit quality on earnings management.

8. To determine the influences of earnings management on firm value. 


\section{Literature Review}

\subsection{Agency Theory}

This study uses Agency Theory as a grand theory derived from Jensen and Meckling (1976) concerning agency relations that a company or entity is a collection of contracts (nexus of contract) between owners of economic resources (principal) between owners or shareholders of a public company and managers (agent) or open company management. Each individual in the contract has an incentive to maximize their respective interests so that it raises agency costs that can erode the value of the company (Watts and Zimmerman, 1986). In an effort to overcome or reduce agency problems mentioned above, these efforts will cause agency costs to be borne by both the principal and the agent. Jensen and Meckling (1976) divide agency costs consisting of monitoring costs, bonding costs and residual loss. Monitoring cost is the cost that arises and is borne by the principal to monitor the agent's behavior or company management. Bonding cost is the cost borne by the agent to determine and comply with a mechanism that guarantees the agent will act for the principal's interests. While residual loss is a sacrifice in the form of reduced principal ability as a result of agent decisions that are different from principal decisions.

In order to monitor the agent's behavior in ensuring that the agent will act in accordance with the wishes of the principal, the principal needs an independent third party as a mediator between the principal and agent. Setiawan (2006) states that independent auditors are third parties who are able to safeguard the interests of principals and agents in managing corporate finances where an independent auditor can perform the monitoring function of the agent's work by using a means in the form of financial statements.

\subsection{Audit Regulation}

In order to improve audit quality, the government issued several regulations governing the supervision of the quality of audit services carried out by KAP with the Minister of Finance Decree No. 423 / KMK.06 / 2002 in 2002, then revised with KMK No. 359 / KMK.06 / 2003 of 2003.During the 2008 global crisis, the government revised the audit regulation with Minister of Finance Regulation No. PMK No.17 / PMK.01 / 2008 year 2008. In the revision of the audit regulation, article 3 emphasizes the limitation on the period of the provision of audit services where the KAP is limited to a maximum of 6 ( $\mathrm{six}$ ) years and the AP is limited to a maximum of 3 (three) years. Restrictions on the audit period are expected to increase auditor independence and public accounting firms so that audit quality is better and there is no longterm dependence and attachment to the audit client.

But over time, there have been quite large cases in the Indonesian Capital Market, namely cases involving several publicly traded companies such as PT Bakrie \& Brothers Tbk (BNBR), PT Bakrie Sumatra Plantations Tbk (UNSP), PT Energi Mega Persada Tbk (ENRG) and PT Benakat Petroleum Energy Tbk (BIPI). In this case, it was found that there was manipulation of the interim financial statements, namely the violation of accounting on deposit funds income at Bank Capital Indonesia (BACA). This accounting violation should be identified by the Public Accountant Office when auditing because there is only one KAP that audits BNBR, UNSP and ENRG. Through the Capital Market and LK Supervisory Agency, the Government issued a Decree of the Chairman of the Capital Market and LK Supervisory Agency Number Kep-86 / BL / 2011 dated February 28, 2011. Which was strengthened by Law No.5 of 2011 which was effective on May 3, 2011 where The Law has a heavier law enforcement element compared to the previous regulation because the Law regulates the 
existence of Criminal Provisions for Public Accountants and Corporations in article 55 where in case of financial manipulation it is punishable by imprisonment of at most 5 (five) years and criminal a maximum fine of 300 million rupiah.

Act No. 5 of 2011 apparently did not provide a clear limitation on detailed and straightforward details about the period of audit services provided to a public accountant. In practice, it was found that the application of Law No.5 of 2011 to the AP audit assignment period could only be implemented properly in the Individual Public Accountant Office. However, in the Partnership Public Accountant Office, the implementation of Law No.5 of 2011 still has a loop hole in limiting the AP assignment period, which in fact is often found by an AP who wants to extend his assignment, so this is done by adding an AP to a particular $\mathrm{KAP}$, for example KAP AB becomes $\mathrm{ABC} \mathrm{KAP}$ and then if the AP assignment period will run out again, then it is again done by adding AP to ABC KAP to become ABCD KAP. This condition can threaten the level of independence of public accountants.

With the above phenomenon, the Government will immediately impose PP No.20 of 2015, in which articles 10 and 11 no longer limit the period of assignment of audit services to the Public Accountant Office, but focus more on limiting the period of audit service assignments by Public Accountants, that is, a maximum of 5 (five) years and can return the audit services within a period of 2 (two) years. Through the enactment of this regulation, it is expected that the level of independence of public accountants as assessors of audit reports is better and can be accounted to the public. It is also felt the importance and urgency of the Financial Services Authority, so OJK through POJK No.13 / POJK.03 / 2017 also includes restrictions on the period of assignment of audit services for Public Accountants no later than 3 (three) years and can give back its audit services within 2 (two years later).

\subsection{Audit Regulation and Audit Quality}

Leuz et al. (2003) found evidence that high levels of earnings management occur in countries with small capital markets, high ownership concentrations, and weak legal enforcement of contractual. They concluded that weak investor protection actually led to a high level of earnings management. Of the 31 non-US firms studied, Indonesia ranked 15th of the highest earnings management score. Therefore, this study wants to examine how far the influence of audit regulations on various forms of earnings management manifestations that might occur in the Indonesian context. In addition, the regulation in the audit services mentioned above may also have an impact on the behavior of public company earnings management. Several previous studies have found a regulatory association with other forms of earnings management. Cohen et al. (2008) and Cohen and Zarowin (2010), for example, found that after the issuance of regulations through the SOX Act in the United States, the behavior of accrual earnings management and the tendency to meet profit targets decreased, but the behavior of real transaction earnings management increased compared to the previous period. Zhou (2008) also found evidence that after the enactment of regulations in audit services and public companies in America, companies not only became more conservative, but also reported absolute discretionary accruals lower. Cohen et al. (2008) and Cohen and Zarowin (2010) found a shift in the pattern of earnings management behavior from accruals to real transactions after the issuance of the SOX Law.

Based on the empirical evidence of the above research, it can be concluded that the application of different audit regulations can influence the relationship between audit quality and earnings management. Based on the discussion above, the researchers compile the following hypotheses: 


\section{H1: Audit regulation has a positive effect on audit Quail}

\subsection{Corporate Governane and Firm Value}

According to Shleifer and Vishny (1997), corporate governance is related to the method by which investors can ensure to get a return on their investment. The definition is in accordance with agency theory which states that governance costs must exist in order to minimize adverse selection and especially ex post moral agency hazard problems. In order to minimize agency costs, a good corporate governance system must be able to combine large types of investors and small investors (Shleifer \& Vishny, 1997, p.739). It also explained that governance is a construction of rules, practices, and incentives to equalize the desires of agents effectively (commissioners and managers) with their principals (investors). In this perspective, company value can be maximized by reducing agency costs and encouraging managers to behave in accordance with the wishes of shareholders. This study, the proxy used is the quality of the board of commissioners and the quality of the audit committee.

Some empirical evidence that concludes that corporate governance can increase corporate value. Eberhart (2012) states that the audit committee system is proven to increase the value of the company compared to just using the auditor. In Siahaan (2013), it was found that the size of the board of directors can positively increase the value of a company. This result is reinforced by other studies which state that the audit committee has a significant effect on firm value (Debby et al, 2010) and the percentage of directors in the board of commissioners and the frequency of meetings of the board of directors significantly influence firm value (Berthelot et al., 2011).

Based on the description above, it was concluded that with good corporate governance, it was hoped that it would increase the value of the company. Previous research results also state that the board of commissioners and audit committee are part of corporate governance from internal governance structures. Based on the discussion above, the researchers compile the following hypotheses:

H2a: The Board of Commissioners has a positive effect on Firm Value.

H2b: The Audit Committee has a positive effect on Firm Value

\subsection{Audit Quality and Firm Value}

Agency theory describes the existence of agency problems caused by two things, managerial compensation and information asymmetry (Jensen \& Meckling, 1976). The first agency problem can be solved by negotiating managerial compensation or managerial ownership. However, the second agency problem is expected to be resolved by the role of an external auditor. The independence of external auditors is expected to provide guarantees to stakeholders that the financial statements prepared by management are free from bias and material errors and in accordance with accounting standards.

Audit quality is an essential component of the quality of financial statements. The higher the audit quality, the higher the credibility of the financial statements. The high credibility of financial statements reflects the basic foundations of a company's economy (DeFond \& Zhang, 2014). High audit quality will tend to be audit reporting of errors and irregularities (Bartov et al., 2000). In addition, high audit quality can increase the relevance value of earnings and book value so as to increase the usefulness of accounting information in the investment decision making process (Alfraih, 2016). Reichelt and Wang (2010) show that auditor specialization is related to company performance. In addition, Ghosh and Moon (2005) also state that long-term auditor-client relationships can enhance client-specific knowledge. 
Finally, Wallace et al. (1994) states that companies audited by Big-4 have more detailed information than Big-4 unaudited companies. This is because Big-4 accounting firms tend to be more professional and the scope of the audit is broader than non-big- 4 accounting firms.

Based on the description above, it can be concluded that audit quality is positively related to the value of the company, namely with the high audit quality, the value of the company increases by itself because the financial statements represent the company's financial position and the results of the company's audited operational results.Based on the discussion above, the researchers compile the following hypotheses:

H3: Audit quality has a positive effect on Firm Value

\subsection{Corporate Governance and Earnings Management}

According to agency theory, earnings management activities can be limited by a good corporate governance that can align the interests of various parties. Corporate governance is a mechanism that can be used by shareholders and corporate creditors to control earnings management activities carried out by management. Good corporate governance is expected to be an obstacle to earnings management activities so as to improve the quality of financial statements. In this study, the proxy used is the quality of the board of commissioners and the quality of the audit committee. There is a lot of empirical evidence that concludes that corporate governance will inhibit or limit earnings management activities. The researcher further discusses the quality of the audit committee in detecting earnings management actions by Xie (2001) examined corporate governance and management behavior in companies listed on US exchanges with a focus on corporate governance mechanisms on CEO quality, also found the number of meetings held by the board of directors, executive committees and audit committees capable of preventing earnings management behavior. However, Carcello and Neal (2000) conclude that earnings management behavior can be reduced if the competence and independence of the audit committee are maintained.

For the Indonesian context, the results of Nasution and Setiawan (2007) concluded that the composition of independent commissioners negatively affected earnings management activities. While Kusumawati and Hermawan (2013), concluded that the effectiveness of the role of the audit committee negatively affects the probability of fraudulent financial reporting. This indicates the effectiveness of the audit committee can reduce the occurrence of fraudulent financial reporting. Based on the description above, it was concluded that with good corporate governance, it was hoped that it would limit opportunistic earnings management activities. Previous research results also state that the board of commissioners and audit committee are part of corporate governance from internal governance structures. Based on the discussion above, the researchers compile the following hypotheses:

H4a: The Board of Commissioners has a negative effect on Earnings Management

H4b: The Audit Committee has a negative effect on Earnings Management

\subsection{Audit Quality and Earnings Management}

De Angelo (1981) defines audit quality as the probability that an auditor finds and reports a violation in the client's accounting system. In the standard financial audit field (SPAP, 2011) states that public accountants are responsible in such a way as to be aware of potential characteristics and types of material irregularities, related to the area being audited, so that public accountants can plan their audits to provide sufficient certainty in detecting material irregularities . A quality auditing process will be able to provide adequate protection and 
confidence that the financial statements are free from material misstatement, whether caused by errors or fraud. Quality auditors are better able to find errors and cheating contained in financial statements because they have better resources and experience.

The results of previous studies have documented that high audit quality can reduce corporate earnings management (Jordan et al., 2010; Yasar, 2013). The results of the study concluded that auditors were able to detect accrual-based earnings management by clients so that auditors made restrictions on aggressive accrual accounting (Chen et al., 2005; Chiang et al., 2011; Sharma et al., 2011). Based on the description above, it can be concluded that audit quality is negatively related to earnings management, namely by the presence of high audit quality, then the possibility of management will make earnings management activities will decrease. Based on the discussion above, the researchers compile the following hypotheses:

\section{H5: Audit quality has a negative effect on Earnings Management}

\subsection{Earnings Management and Firm Value}

The results of Bitner and Dolan's (1996) study show that equity markets ignore earnings management through real transactions and earnings management through changes in accounting procedures or methods. The research also shows that although earnings management can be detected by the stock market, the stock market or investors ignore the information about the profit engineering. This reflects that earnings management is considered by investors as a general matter or is considered a management strategy that will not risk the investment.

Managers as agents who have authority in a company know more about the internal information and prospects of the company in the future compared to shareholders (owners). The separation of roles and differences in interests between managers and shareholders is a trigger for actions to maximize the welfare of certain parties, such as taking earnings management actions. Earnings management can indeed increase the value of the company, but is limited in certain periods and will not increase the value of the company in the long run. Darwis (2012) states that even though earnings management will increase the value of the company in a certain period, actually earnings management will reduce the value of the company in the future.

Bao and Bao (2004) show that income smoothing which is one of the proxies of earnings management is positively related to the profit per share as a proxy for shareholder value. Earnings management can actually increase productivity and sales volume so that company profits increase. This reflects that earnings management is for the benefit of shareholders' prosperity. There is an impression that the manager does not act opportunistically for his own sake but instead prioritizes the prosperity of shareholders, because he hopes to get additional bonuses from the owner. So it can be concluded that the lower earnings management, the greater the shareholder value. Based on the results of the above research, it can be concluded that earnings management is negatively related to the value of the company. Based on the discussion above, the researchers compile the following hypotheses:

H6: Earnings Management has a negative effect on Firm Value 


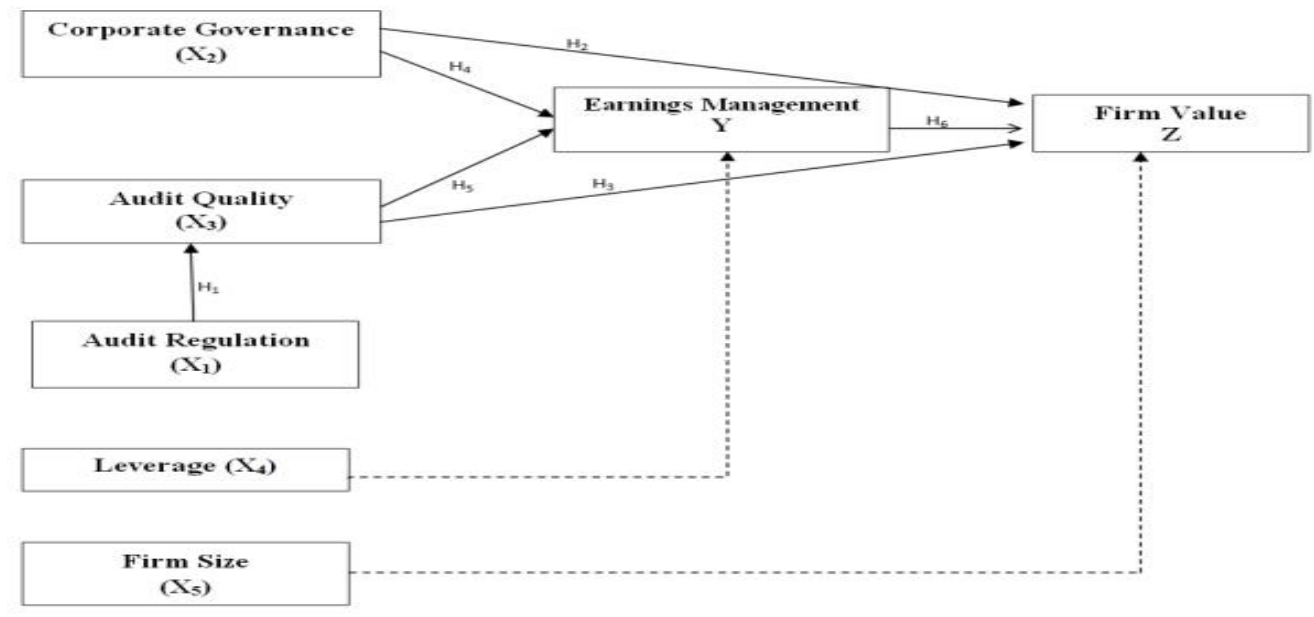

Figure 1. Conceptual Framework

\section{Methodology}

Research Subject: The population in this study were all companies listed on the Stock Exchange in 2008 to 2015 ( 8 years). Sample selection is done by purposive sampling method. The following are the criteria for selecting research samples:

1. Public Go Company engaged in the Manufacturing sector.

2. Issued its annual financial statements ending on December 31, starting from 2008 to 2015 and fully operational during the year, and excluding new listing companies (IPOs) between the periods of observation.

3. Never been delisted from the IDX, did not stop the activity, did not stop its operations on the IDX, did not merge, and did not change the status of the industrial sector during 2008-2015. 
4.

Table 1. Research sample selection

\begin{tabular}{lc}
\hline Kriteria & Jumlah Emiten \\
\hline Manufacture Sector Emitens & 170 \\
Emitens that listed in 2007 & $(50)$ \\
Emitens have discomplete annual report and & $(51)$ \\
financial report in 2007-2015 & \\
\hline Total & $\mathbf{6 9}$ \\
\hline
\end{tabular}

In the process of selecting research samples, the study population of 170 issuers was reduced by the number of issuers registered in 2007 by 50 issuers and the number of issuers that did not have the completeness of the annual report and financial statements for the 20082015 period of 51 issuers. The complete report that is not presented is detected based on the checklist of indicators of the board of commissioners and audit committee, if it is not complete, the issuer is not included as a sample, so the total sample in this study is 69 issuers. This selection is done so that the research sample used must have the same number of financial and annual reports.

Data collection and materials in this study were carried out by literature study by collecting data and processing the data to solve problems in this study. Data splitting comes from financial report documentation and annual reports accessed through www.idx.co.id and stock reports accessed through www.finance.yahoo.com.

Table 2. Operational Variables (1)

\begin{tabular}{|c|c|c|c|}
\hline Variable & Scale & Measurement & Reference \\
\hline \multicolumn{4}{|c|}{ Independen } \\
\hline $\begin{array}{l}\text { Audit } \\
\text { Regulation }\end{array}$ & Ordinal & $\begin{array}{l}\text { 1. Period audit regulation in } \\
2008-2010 \text { is given score } 1 \\
\text { (one) } \\
\text { 2. Period audit regulation in } \\
2012-2014 \text { is given score } 2 \\
\text { (two) } \\
\text { 3. Period audit regulation in } \\
2015 \text { is given score } 3 \text { (three) }\end{array}$ & $\begin{array}{l}\text { Developed in } \\
\text { dissertation }\end{array}$ \\
\hline $\begin{array}{l}\text { Corporate } \\
\text { Governance }\end{array}$ & Ordinal & 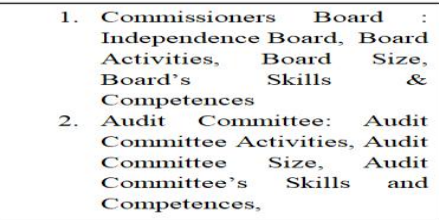 & \begin{tabular}{|l|} 
Hermawan \\
$(2011)$
\end{tabular} \\
\hline $\begin{array}{l}\text { Audit } \\
\text { Quality }\end{array}$ & Ordinal & Audit Quality Score) & \begin{tabular}{|l|} 
Herusetya \\
$(2012)$
\end{tabular} \\
\hline \multicolumn{4}{|c|}{ Intervening } \\
\hline $\begin{array}{l}\text { Earnings } \\
\text { Management }\end{array}$ & Ratio & $\begin{array}{l}\text { Performance matched discretionary } \\
\text { accrual }\end{array}$ & $\begin{array}{l}\text { Kothari et al. } \\
\text { (2005) }\end{array}$ \\
\hline \multicolumn{4}{|c|}{ Dependen } \\
\hline Firm Value & Ratio & Book Value per Share & $\begin{array}{l}\text { Wulandari } \\
(2009)\end{array}$ \\
\hline \multicolumn{4}{|c|}{ Kontrol } \\
\hline Leverage & Ratio & $\begin{array}{l}\text { Debt to Equity Ratio } \\
\text { Debt to Assets Ratio }\end{array}$ & $\begin{array}{l}\text { Juningan } \\
(2011)\end{array}$ \\
\hline Firm Size & Ratio & $\begin{array}{l}\text { Total Sales } \\
\text { Total Assets }\end{array}$ & $\begin{array}{l}\text { Sujoko \& } \\
\text { Subiantoro } \\
(2007)\end{array}$ \\
\hline
\end{tabular}


In an effort to determine the relationship between variables simultaneously, a multivariate statistical method is needed that can analyze more than two variables. The software used to help SEM analysis is Partial Least Square (PLS). PLS uses an iteration algorithm consisting of OLS (Ordinary Least Squares) series so that the problem of model identification is not a problem for recursive models (models that have one direction causality) and avoid problems for non-recursive models (reciprocal models or reciprocal between variables) which can be solved by covariance-based SEM (Ghozali \& Latan, 2015).

The following is a breakdown of the research equation model:

\begin{tabular}{|c|c|c|c|}
\hline & & & \\
\hline Model 1 & AUD $_{i}=$ & $=\beta_{0}+\beta_{1} R_{E G}+\varepsilon_{i}$ & $(3.1)$ \\
\hline $\begin{array}{l}\text { Model } 2 \\
\text { Model } 3\end{array}$ & $\begin{array}{l}\mathrm{EARN}_{i} \\
\text { EARN1 }_{i}\end{array}$ & 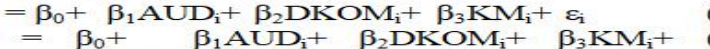 & $\begin{array}{l}(3.2) \\
(3.3)\end{array}$ \\
\hline Model 4 & VALUE & $\begin{array}{l}\beta_{4} \mathrm{DER}_{\mathrm{i}}+\beta_{5} \mathrm{DAR}_{\mathrm{i}}+\varepsilon_{\mathrm{i}} \\
=\beta_{\mathrm{o}}+\beta_{1} \mathrm{AUD} \\
\beta_{4} \mathrm{EARN}_{\mathrm{i}}+\boldsymbol{\varepsilon}_{\mathrm{i}}\end{array}$ & $(3.4)$ \\
\hline Model 5 & VALUE 1 & $\begin{array}{c}1_{\mathbf{i}}=\beta_{0}+\beta_{1} \text { AUD }_{i}+\beta_{2} \text { DKOM }_{i}+\beta_{3} \mathrm{KM}_{\mathbf{i}}+ \\
\beta_{4} \text { EARN }_{\mathbf{i}}+\beta_{5} \text { ASET }_{\mathbf{i}}+\beta_{6} \text { SALES }_{i}+\varepsilon_{\mathbf{i}}\end{array}$ & (3.5) \\
\hline \multicolumn{4}{|c|}{ Keterangan : } \\
\hline $\boldsymbol{\beta}_{0}-\boldsymbol{\beta}_{5}$ & & \multicolumn{2}{|l|}{$=$ Coefficient } \\
\hline REG & & \multicolumn{2}{|l|}{$=$ Audit Regulation } \\
\hline DAR & & \multicolumn{2}{|l|}{$=$ Debt Asset Ratio } \\
\hline DER & & \multicolumn{2}{|l|}{$=$ Debt Equity Ratio } \\
\hline ASET & & \multicolumn{2}{|l|}{$=$ Total Asset } \\
\hline SALES & & \multicolumn{2}{|l|}{$=$ Total Sales } \\
\hline EARN & & \multicolumn{2}{|l|}{ = Earning Management } \\
\hline EARN1 & & \multicolumn{2}{|l|}{$\begin{array}{l}\text { = Earnings Management which variable control } \\
\text { are DAR and DER }\end{array}$} \\
\hline DKOM & & \multicolumn{2}{|l|}{$=$ Commissioner Board } \\
\hline $\mathrm{KM}$ & & \multicolumn{2}{|l|}{$=$ Audit Committee } \\
\hline AUD & & \multicolumn{2}{|l|}{$=$ Audit Quality } \\
\hline VALUE & & \multicolumn{2}{|l|}{$=$ Firm Value } \\
\hline \multicolumn{2}{|l|}{ VALUE1 } & \multicolumn{2}{|l|}{$\begin{array}{l}\text { Firm Value which variable control are Total } \\
\text { Sales and Total Asset }\end{array}$} \\
\hline$\varepsilon$ & & $=$ error & \\
\hline
\end{tabular}

\section{Results}

\subsection{Descriptive Statistics}

The unit of analysis in this study are companies listed on the Stock Exchange in accordance with the IDX Fact Book in 2014. The sample was taken based on purposive sampling, namely companies engaged in the Manufacturing sector for the period 2008 - 2015. The total sample was 69 companies with 8 years of observation year so that the overall study was 552 years of observation. But in testing normality using AMOS 22.0, the number of samples became 480 observations where 72 observations were omitted and considered as outliers. 
Table 3. Descriptive Statistics

\begin{tabular}{lccccc}
\hline V ariabel & $\mathrm{N}$ & Minimum & Maximum & Mean & Std. Deviation \\
\hline Commissioner Board & 480 & 1.000 & 2.533 & 1.777 & .289 \\
Audit Committee & 480 & 1.00 & 3.00 & 2.165 & .559 \\
Audit Quality & 480 & 0 & 1 & .343 & .299 \\
Earnings & 480 & -.623 & .423 & -.068 & .153 \\
Management & 480 & .000 & .013 & .002 & .002 \\
Firm Value & 480 & 9.608 & 18.463 & 14.334 & 1.701 \\
Firm Size1 & 480 & 7.031 & 18.405 & 14.436 & 1.708 \\
Firm Size2 & 480 & -30.598 & 322.267 & 2.995 & 18.769 \\
DER & 480 & .000 & 411.040 & 1.559 & 18.832 \\
DAR & 480 & & & & \\
Valid N (listwise) & & & & & \\
*Firm Size1 : total asset & & & & & \\
Firm Size2 : total sales & & & & &
\end{tabular}

\subsection{Outer Model Analisis}

This study uses 5 latent variables namely board of commissioners, audit committee, audit quality, earnings management, and company value. The Board of Commissioners variable consists of 17 indicators, the audit committee consists of 11 indicators, audit quality consists of 1 indicator, earnings management consists of 1 indicator and finally firm value consists of 1 indicator. Evaluation of the measurement model of latent variables with formative indicators based on substantive content is by comparing the relative weight and seeing the significance of the weight size (Chin, 1998).

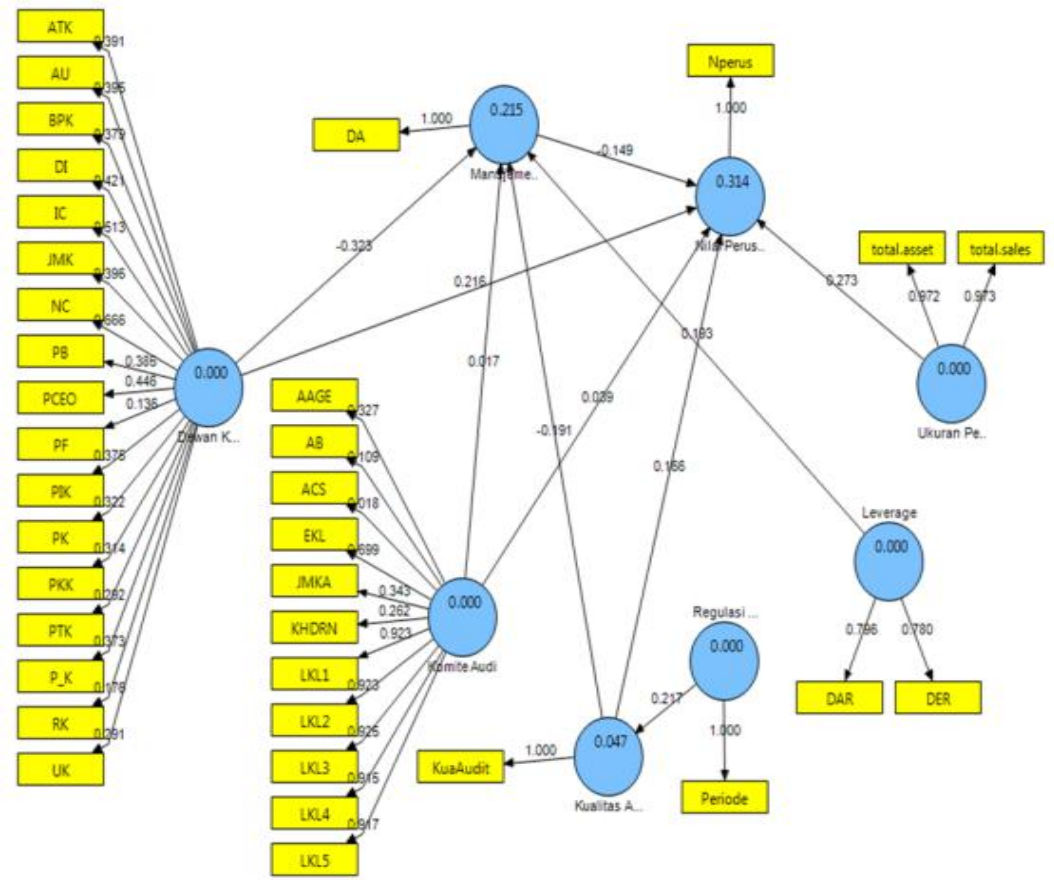


Figure 2. Outer Model

Test evaluation of the outer model concludes that:

1. 17 Board of Commissioners' indicators show significance with t-statistics above 1.645. This means that all indicators used to reflect the board of commissioner's variables are valid. So that the board commissioner variable as an unobserved variable can be accepted. Among the 17 indicators, the NC Indicator (Nominating Committee) is more strongly reflecting the board of commissioners with a t-statistic value of 4,959.

2. 11 indicators of the Audit Committee show significance with t-statistics above 1.645. This means that all indicators used to reflect the audit committee variables are valid. So that the audit committee variable as an unobserved variable can be accepted. Among the 11 indicators, the EKL indicator (Full Audit Committee Evaluation) is more strongly reflecting the board of commissioners with a t-statistic value of 2,693.

3. For the variables of Audit Quality, Profit Management and Firm Value, there is no tstatistic result because it only uses 1 indicator which cannot be processed by the SmartPLS 3.0 statistical tool.

\subsection{Inner Model Analysis}

Evaluation of Goodness of Fit Structural models were measured using predictiverelevance $(\mathrm{Q} 2)$. Predictive-relevance values are calculated by the formula:

$\mathrm{Q} 2=1-(1-\mathrm{R} 12)(1-\mathrm{R} 22) \ldots(1-\mathrm{Rm} 2) \mathrm{R}^{2}$ values for each dependent / intervening variable can be seen in table 3 .

Table 4. Inner Model Results

\begin{tabular}{lc}
\hline \multicolumn{1}{c}{ Variable } & R-Square \\
\hline Audit Quality & 0.047 \\
Earnings Management & 0.215 \\
Firm Value & 0.313 \\
Predictive-relevance $\left(Q^{2}\right)$ & 0.575 \\
\hline
\end{tabular}

Overall predictive-relevance of 0.575 or $57.5 \%$ means that the model is able to explain the phenomenon of corporate value by $57.5 \%$, while the remaining $42.5 \%$ is explained by other variables that have not entered the model.

\subsection{Hypotheses Analysis}

One-tailed hypothesis testing is done by looking at the results of the $t$ value at a $90 \%$ confidence level (significance level of 10\%) and the path coefficient (Beta) of each relationship between the variables hypothesized. The one tailed hypothesis is stated to be significant if the statistics $>1.645$ (Hair et al., 2012). 
Table 5. Hypotheses Results

\begin{tabular}{|c|c|c|c|c|c|c|}
\hline Hip. & Model & Prediction & Estimate & t-statistik & Results & Decision \\
\hline 1 & $\begin{array}{l}\text { Audit Regulation } \rightarrow \\
\text { Audit Quality }\end{array}$ & + & 0.217 & 2.175 & $\begin{array}{l}\text { Significant and } \\
\text { Positive }\end{array}$ & $\mathrm{H}_{1}$ accepted \\
\hline $2 \mathrm{a}$ & $\begin{array}{l}\text { Commissioners Board } \rightarrow \\
\text { Firm Value }\end{array}$ & + & 0.216 & 2.072 & $\begin{array}{l}\text { Significant and } \\
\text { Positive }\end{array}$ & $\mathrm{H}_{2 \mathrm{a}}$ accepted \\
\hline $2 \mathrm{~b}$ & $\begin{array}{l}\text { Audit Committee } \rightarrow \\
\text { Firm Value }\end{array}$ & + & 0.039 & 0.315 & No Significant & $\mathrm{H}_{2 \mathrm{~b}}$ rejected \\
\hline 3 & $\begin{array}{l}\text { Audit Quality } \rightarrow \text { Firm } \\
\text { Value }\end{array}$ & + & 0.166 & 1.887 & $\begin{array}{l}\text { Significant and } \\
\text { Positive }\end{array}$ & $\mathrm{H}_{3}$ accepted \\
\hline $4 a$ & $\begin{array}{l}\text { Commissioners } \\
\text { Board } \rightarrow \text { Earnings } \\
\text { Management }\end{array}$ & - & -0.323 & -3.152 & $\begin{array}{l}\text { Significant and } \\
\text { Negative }\end{array}$ & $\mathrm{H}_{4 \mathrm{a}}$ accepted \\
\hline $4 b$ & $\begin{array}{l}\text { Audit Committee } \rightarrow \\
\text { Earnings Management }\end{array}$ & - & -0.017 & -0.135 & No Significant & $\mathrm{H}_{4 \mathrm{~b}}$ rejected \\
\hline 5 & $\begin{array}{l}\text { Audit Quality } \rightarrow \\
\text { Earnings Management }\end{array}$ & - & -0.191 & -2.251 & $\begin{array}{l}\text { Significant and } \\
\text { Negative }\end{array}$ & $\mathrm{H}_{5}$ accepted \\
\hline 6 & $\begin{array}{l}\text { Earnings Management } \\
\rightarrow \text { Firm Value }\end{array}$ & - & -0.149 & -1.704 & $\begin{array}{l}\text { Significant and } \\
\text { Negative }\end{array}$ & $\mathrm{H}_{6}$ accepted \\
\hline
\end{tabular}

Table 5 shows that audit regulation influences positively on audit quality. Commissioners board and audit quality influence positively on firm value and earnings management. However, audit committee doesn ${ }^{\text {ec }}$ influence on firm value and earnings management. Lastly, earnings management influences negatively on firm value.

\section{Discussion}

Based on hypothesis 1 , the role of audit regulation in strengthening the influence of audit quality on earnings management is in line and in accordance with agency theory where audit regulation is an audit standard that must be followed by the auditor in the audit process. Detailed audit regulations and strict sanctions can limit the gray area that is used by the auditor and management to carry out earnings management actions simultaneously. Audit regulations can also increase the independence of public accountants so that in the process of auditing they do not collide with conflict of interest from the management. 
Based on the hypotheses, the mechanism of corporate governance that is effective for increasing the value of the company is the board of commissioners. The uncertainty of the audit committee variable on the value of the company due to the appointment and authentication of the audit committee is determined by the board of commissioners so that the independence of the audit committee is still in doubt. In addition, the percentage of the independent audit committee has not been optimal in the composition of the company's audit committee.

Based on hypothesis 3, the higher the audit quality, the higher the credibility of the financial statements. The high credibility of financial statements reflects the basic foundations of a company's economy (DeFond \& Zhang, 2014). High audit quality will tend to be audit reporting of errors and irregularities (Bartov et al, 2000). In addition, high audit quality can increase the relevance value of earnings and book value so as to increase the usefulness of accounting information in the investment decision making process (Alfraih, 2016). This result is in line with several studies (DeFond \& Zhang, 2014; Alfraih, 2016) which concludes that audit quality can increase firm value.

Based on hypothesis 4, an effective corporate governance mechanism for decreasing earnings management is the board of commissioners. This is in line with agency theory where corporate governance is a monitoring mechanism for principals on the activities of management within the company. The board of commissioners and audit committee are external parties of company management so they are not involved in a conflict of interest.

Based on hypothesis 5, the influence of audit quality on earnings management is in line and in accordance with agency theory where in order to conduct monitoring activities of agent behavior to ensure that the agent acts in accordance with the principal's interest, the principal requires an independent third party as a mediator between the principal and agent. These third parties are external public accountants. Analysis and auditing of financial reports by external parties can bring up findings in company management activities such as moral hazard actions. That is why in the review of financial statements, the auditor states the audit opinion based on the findings in the financial statements. This evaluation from third parties can be a mitigator for management in taking earnings management actions.

Based on hypothesis 6 , the influence of earnings management on the value of the company is in line and in accordance with the agency theory where in the agency relationship, each individual in the contract has an incentive to maximize their respective interests so as to incur agency costs that can reduce the value of the company (Watts and Zimmerman, 1986). So, the higher earnings management within the company, the company assets and profits listed in the financial statements are not in accordance with the actual value of the company. This is what can affect the company's valuation of valuable companies in the future.

\section{Limitations Of The Study}

Due to the incompleteness of audit fees in the financial and annual reports, the audit fees as a proxy for Client Importance are not used as an indicator of audit quality. In addition, there are data outliers that reduce the number of research samples. Finally, the number of issuers per period of the implementation of audit regulations is not the same, namely the 2008-2010 period ( 3 years), the 2011-2014 (4 years) period and the 2015 period ( 1 year). This causes the empirical analysis to be disproportionate. 


\section{Conclusion}

Empirical results show that audit regulation influences positively on audit quality. Commissioners board and audit quality influence positively on firm value and earnings management. However, audit committee doesn"t influence on firm value and earnings management. Lastly, earnings management influences negatively on firm value.

The results of this study can provide new input on audit regulation because changes in audit regulations are proven to minimize earnings management that occurs in the company. Audit regulations can strengthen determinant factors such as audit quality in order to reduce earnings management within the company. These results are consistent with the findings of Cohen et al. (2008) which states that earnings management activities can be reduced because audit regulation can strengthen the relationship between audit quality and earnings management.

For the Financial Services Authority, this research can provide input on the importance of making new regulations in reducing fraud in finance such as earnings management. One of them is audit regulation which has an impact on reduced levels of earnings management. In addition, this study gives consideration to the Financial Services Authority in using internal and external factors of the company in reducing earnings management such as the board of commissioners and audit quality.

Future research may consider adding indicators of corporate governance mechanisms such as renumeration / nomination committees because this committee determines the amount of compensation and the recruitment requirements of directors. This committee can be a preventive corporate governance tool. In addition, the measurement of audit quality can be added to the client importance indicator. Finally, this research can provide new considerations in analyzing the company's performance through a different approach, namely how tightly the company follows and implements regulations so that the compliance factor of audit regulations can be analyzed for further research.

\section{References}

[1]. Alfraih, M.M. (2016), The Role Of Audit Quality In Firm Valuation: Evidence From An Emerging Capital Market With A Joint Audit Requirement, International Journal Of Law And Management, Vol. 58 Issue: 5, Pp.575-598

[2]. Bao, B.H. \& Bao, D.H. (2004), Income Smoothing, Earnings Quality And Firm Valuation. Journal Of Business Finance \& Accounting, 31, 9-10, Pp.1525-1557.

[3]. Baye, M.R. \& Prince, J.T. (2014), Managerial Economics And Business Strategy, 8th Edition. Mcgraw-Hill, 2014.

[4]. Berthelot, S., Francoeur, C. \& Labelle, R. (2011), Corporate Governance Mechanism, Accounting Results And Stock Valuation In Canada, Internationaljournal Of Managerial Finance, Vol. 8 (4), Pp.332-343.

[5]. Brigham, E. F. \& Houston, J.F. (2001). Fundamentals Of Financial Management. Nineth Edition. United States Of America: Horcourt College.

[6]. Carcello, J. \& Neal, T. (2000), Audit Committee Composition And Auditor Reporting. The Accounting Review 75 (2000):453-67.

[7]. Chen, K.Y., Lin, K. \& Zhou, J. (2005), Audit Quality And Earnings Management For Taiwan IPO Firms. Managerial Auditing Journal, 20,1.

[8]. Chiang, S., Huang, L. \& Hsiao, H. (2011), Study Of Earnings Management And Audit Quality. African Journal Of Business Management Vol. 5(7), Pp. 2686-2699, 4 April, 2011 
[9]. Chin, W.W. (1998). The Partial Least Squares Approach For Structural Equation Modeling. In G.A. Marcoulides (Ed.), Modern Methods For Business Research (Pp. 236-295). London: Lawrence Erlbaum Associates.

[10]. Cohen, D.A. \& Zarowin, P. (2010). Accrual-Based And Real Earning Management Activities Around Seasoned Equity Offerings. Journal Of Accounting And Economics, Article In Press January 2010, Doi:10.1016/J.Jacceco.2010.01.002.

[11]. Cohen, D.A., Dey, A. \& Lys, T.Z. (2008). Real And Accrual Based Earnings Management In The Pre- And Post-Sarbanes Oxley Periods. The Accounting Review, 83, 3, 757-787.

[12]. Darwis, H. (2012). Manajemen Laba Terhadap Nilai Perusahaan Dengan Corporate Governance Sebagai Pemoderasi. Jurnal Keuangan Dan Perbankan, Vol. 16, No.1, Januari 2012, Hal 45-55.

[13]. Debby, J.F., Muktharuddin, Yuniarti, E., Saputra, D. \& Abukosim. (2010), Good Corporategovernance,Company"s Characteristics And Firm 'S Value: Empirical Study Of Listed Banking On Indonesian Stock Exchange, GSTF Journal On Business Review Vol 3 (4), Pp. 81-88.

[14]. Deangelo, L.E. (1981). Auditor Size And Audit Quality.Journal Of Accounting And Economics, 3, 183-199.

[15]. Dechow, P.M. \& Skinner, D. (2000). Earnings Management: Reconciling The Views Of Accounting Academics, Practitioners, And Regulators. Accounting Horizons 14, 2, 235-250.

[16]. Defond,M.\& Zhang,Z.(2014), “Are View Of Archival Auditing Research”, Journal Of Accounting And Economics, Vol. 58 No. 2/3, Pp. 327-338.

[17]. Eberhart, R. (2012), Corporate Governance Systems And Firm Value: Empirical Evidencefromjapan 'Snatural Experiment, Journal Of Asia Business Studies, Vol.6 (2), Pp. 176196.

[18]. Fama, E. F. (1978). The Effects Of A Firme'S Investment And Financing Decisions On The Welfare Of Its Security Holders". The American Economic Review. 272-284.

[19]. Ghosh, A. \& Moon, D. (2005). Auditor Tenure And Perceptions Of Audit Quality. The Accounting Review, 80, 2, 585-612.

[20]. Ghozali, I. Dan Latan, H. (2015). Partial Least Squares Konsep, Teknik Dan Aplikasi Menggunakan Program Smartpls 3.0 Untuk Penelitian Empiris. Badan Penerbit Universitas Diponegoro, Semarang.

[21]. Gunny, K. (2009). The Relation Between Earnings Management Using Real Activities Manipulation And Future Performance: Evidence From Meeting Earning Benchmarks. University Of Colorado. Working Paper, Available At Http://Www.Ssrn.Com.

[22]. Hair, J.F., Sarstedt, M., Ringle, C.M., \& Mena, J.A. (2012). An Assessment Of The Use Of Partial Least Squares Structural Equation Modelling In Marketing Research. Journal Of The Academy Of Marketing Science, 40(1), 414-433.

[23]. Hermawan, A.A. (2011). The Influence Of Effective Board Of Commissioers And Audit Committee On The Informativeness Of Earnings: Evidence From Indonesian Listed Firms.Asia Pacific Journal Of Accounting And Finance. Vol 2 (1).

[24]. Herusetya, A.(2012). Analisis Audit Quality Metric Score (AQMS) Sebagai Pengukur Multidimensi Kualitas Audit Terhadap Manajemen Laba Dan Kandungan Informasi Laba. Disertasi Depok. Program Pasca Sarjana Ilmu Akuntansi Fakultas Ekonomi Universitas Indonesia (Tidak Dipublikasikan).

[25]. Jensen \& Meckling. (1976). Theory Of The Firm: Managerial Behaviour, Agency Cost And Ownership Structure.Journal Of Financial Economics. October 1976.

[26]. Jordan, C.E., Clark, S.J. \& Hames, C.C. (2010). The Impact Of Audit Quality On Earnings Management To Achieve User Reference Points In EPS. The Journal Of Applied Business Research Vol.26 No.1, Pp. 19-30.

[27]. Jumingan. (2011), Analisis Laporan Keuangan. Jakarta. Bumi Aksara

[28]. Kothari, S.P., Leone, A.J. \& Wasley, C.E. (2005). Performance Matched Discretionary Accrual Measures. Journal Of Accounting And Economics, 39, 163- 197.

[29]. Kusumawati, S.M. \& Hermawan, A.A.(2013). The Influence Of Board Of Commissioners And Audit Committee Effectiveness, Ownership Structure, Bank Monitoring, And Firm Life Cycle On Accounting Fraud.Jurnal Akuntansi Dan Keuangan Indonesia. Vol 10 Nomor 1. 
[30]. Leuz, C., Nanda, D. \& Wysocki, P.D.(2003). Earnings Management And Investor Protection: An International Comparison.Journal Of Financial Economics, 69, 3, 505-527.

[31]. Molejadi, Supriyati, T.S. (2014), Factors Affecting Firm Value : Theoretical Study On Public Manufacturing Firms In Indonesia. South East Asia Journal Of Contemporary Business, Economics And Law, 5 (2), Pp. 6-15.

[32]. Nasution, M \& Setiawan, D. (2007). Pengaruh Corporate Governance Terhadap Manajemen Laba Di Industri Perbankan Indonesia. Simposium Nasional Akuntansi X, Makasar, 26-28 Juli 2007.

[33]. Reichelt, K. J., \& Wang, D. (2010). National And Office-Specific Measures Of Auditor Industry Expertise And Effects On Audit Quality. Journal Of Accounting Research, 48(3), 647-686. Http://Dx.Doi.Org/10.1111/J.1475-679X.2009.00363.

[34]. Setiawan, Rahmat. (2006). "Faktor-Faktor Yang Mempengaruhi Struktur Modal Dalam Perspektif Pecking Order Theory: Studi Kasus Pada Industri Makanan Dan Minuman Di BEJ". Majalah Ekonomi Th.XVI Nomor 3 Desember : 318-334

[35]. Sharma, V.D., Sharma, D.S. \& Ananthanarayanan, U. (2011), Client Importance And Earnings Management : The Moderating Role Of Audit Committees. Auditing: A Journal Of Practice \& Theory Vol.30 No.3, Pp.125-156.

[36]. Shleifer, A.\& Vishny, R. W. (1997), A Survey Of Corporate Governanc ,The Journal Of Finance, Vol. 50, No. 2, Pp. 737-783.

[37]. Siallagan. H, Dan M. Machfoedz. 2006. Mekanisme Corporate Governance, Kualitas Laba Dan Nilai Perusahaan. Simposium Nasional Akuntansi IX.

[38]. Siahaan, F.O.P. (2013). The Effect Of Good Corporate Governance Mechanism, Leverage, And Firm Size On Firm Value. GTSF Journal On Business Review (GBRI) Vol.2 No.4, July, 137-142.

[39]. Sudiyatno, B., Puspitasari, E. \& Kartika, A. (2012), The Company ${ }^{\text {ee } S ~ P o l i c y, ~ F i r m ~ P e r f o r m a n c e, ~}$ And Firm Value : An Empirical Research On Indonesia Stock Exchange. American International Journal Of Contemporary Research, Vol.2 No.12, Pp.30-40.

[40]. Sujoko \& Subiantoro, U., (2007), Pengaruh Struktur Kepemilikan Saham, Leverage, Faktor Intern Dan Faktor Ekstern Terhadap Nilai Perusahaan, Jurnal Manajemen Dan Kewirausahaan, Vol 9, 47.

[41]. Wallace, R. S. O., Naser,K.Andmora,A.(1994 ),“Therelationshipbetweenthecomprehensi Veness Of Corporate Annual Reports And Firm Characteristics In Spain”, Accounting And Business Research,Vol.25No.97,P.41.

[42]. Watts, R. L. \& Zimmerman, J.L. (1986). The Positive Accounting Theory. Prentice Hall, Inc. New Jersey.

[43]. Wulandari, Dhita Ayudia. 2009. Analisis Faktor Fundamental Terhadap Saham Industri Pertambangan Dan Pertanian Di BEI. Universitas Gunadarma. Jurnal Akuntansi Dan Keuangan.

[44]. Xie, H. (2001). The Mispricing Of Abnormal Accruals. The Accounting Review, Vol 76, No.3: 357-373

[45]. Yassar, A. (2013). Big Four Auditorsee Audit Quality And Earnings Management : Evidence From Turkish Stock Market. International Journal Of Business And Social Science Vol.4 No.17, Pp.153-163. 